Edwin A. M. Gale

\title{
Troglitazone: the lesson that nobody learned?
}

Published online: 16 December 2005

C) Springer-Verlag 2005

\section{Morlocks and Eloi}

H. G. Wells once wrote a story about a man who travelled in time to a future world. There he encountered members of a beautiful race called the Eloi, who lived carefree lives of sylvan innocence on the surface of the planet, and tried hard to ignore the existence of the Morlocks, an ugly race that lived out of sight under the ground and preyed upon the Eloi for food and slaves. It would of course be too extreme to suggest that this might be taken as a parable of the relationship between the medical profession and the pharmaceutical industry, but there can be no doubt that there are things the medical Eloi prefer not to know, and that the pharmaceutical Morlocks choose not to talk about. The troglitazone story is among them.

In 1997, Audrey LaRue Jones volunteered to take part in a major diabetes prevention trial, sponsored by the National Institute of Diabetes and Digestive and Kidney Diseases (NIDDK), which was one of the most ambitious clinical studies ever launched $[1,2]$. An otherwise healthy 55 -yearold school teacher on no medication, she had impaired glucose tolerance, and was therefore at risk of progression to diabetes. The study was designed to prevent this from happening. She was randomised to a newly introduced agent called troglitazone. Seven months later, despite regular monitoring of liver enzymes, she went into fulminant liver failure and died on 17 May 1998 following an unsuccessful liver transplant [3]. The NIDDK announced on June 4th that it would be terminating the troglitazone arm of its study [4], and the manufacturers, Warner-Lambert, issued a press release claiming that Audrey had died of 'complications unrelated to the study or the diabetes medication' [5].

Four years previously, in November 1994, an article in the New England Journal of Medicine reported a study with

\footnotetext{
E. A. M. Gale $(\bowtie)$

Diabetes and Metabolism, Medical School Unit,

Southmead Hospital,

Bristol, BS10 5NB, UK

e-mail: Edwin.Gale@bristol.ac.uk

Tel.: +44-117-9595337

Fax: +44-117-9595336
}

troglitazone (marketed as Rezulin), then a novel drug in development, and suggested that its actions in reducing insulin resistance might prove of value in the prevention of type 2 diabetes [6]. Jerrold Olefsky, the senior author, had his name on a US patent for the use of thiazolidinediones in diabetes prevention [7] and was soon to have his name on another [8]. He went on to chair the panel that in 1995 approved the use of troglitazone in the NIDDK trial in which Audrey LaRue Jones would participate, but abstained from the final vote endorsing its use. Richard Eastman, the well-respected director of the NIDDK Division of Diabetes, also consulted for Warner-Lambert. He received US $\$ 78,455$ from them in the form of consulting fees, curriculum development and travel expenses related to the launch of Rezulin. 'Curriculum development' referred to his work on the Rezulin speakers' panel and a not-for-profit educational foundation known as the National Diabetes Education Initiative, which was supported by WarnerLambert. These activities had been declared in advance to his employers and approved by them, and he had recused himself (abstained) from voting on the panel that chose troglitazone. He was later to lose his job in consequence [9].

Parke-Davis (the research division of Warner-Lambert) had meanwhile been pushing for regulatory approval by the Food and Drug Administration (FDA). The FDA, long notorious for its ultra-conservative attitude to drug safety, now stood accused of dragging its feet over approval of drugs for AIDS. A well-orchestrated political lobby would claim that bureaucratic inertia was depriving the American public of valuable new therapies. A new fast-track approval pathway was the result, and troglitazone was the first drug to go down it. Thus it was that the Agency that had kept metformin off the US market for 25 years now let troglitazone through in 6 months [10].

Not everyone had been convinced of its value. FDA medical officer John Gueriguian stated in August 1996 that troglitazone 'offered very little significant therapeutic advantage' over existing therapies for diabetes, and later expressed his concern over the high rates of liver injury and heart failure (16 vs $7 \%$ in controls for the latter complication) reported by two Phase III trials [3]. His October 1996 
report recommended rejection of the drug, and commented on 'the propensity of the company to dismiss a possible association between Rezulin and adverse events', whilst asking whether they had 'gone into denial mode'. One year previously, Warner-Lambert had admitted to felony, having deliberately misled the FDA about the quality and contents of some of its products. The company was fined a record US $\$ 10$ million, and criminal proceedings were lodged against the vice-president in charge of quality control [11]. It now protested Gueriguian's 'intemperate' language, with the result that the Agency took him off their evaluation panel on 4 November 1996, and removed his medical review from the files [3].

Gueriguian's report was passed on to Parke-Davis, but was not shown to the FDA advisory panel that voted to give troglitazone fast-track approval on 11 December 1996 [12]. Randall Whitcomb of Parke-Davis testified to the panel that the incidence of liver damage with troglitazone was comparable to that with placebo. The accuracy of this statement can be judged from the package insert supplied with the drug at launch in March 1997. This stated that 'During all clinical studies in North America ( $n=2,510$ patients) a total of 20 Rezulin-treated patients were withdrawn from treatment because of liver function test abnormalities. Two of the 20 patients developed reversible jaundice. Both had liver biopsies which were consistent with an idiosyncratic drug reaction.' A later section explained that $2.2 \%$ of Rezulin-treated patients showed increases in the liver enzyme alanine aminotransferase (ALT, a marker of liver cell damage) three times above the normal range, as against $0.6 \%$ of those on placebo [13]. This warning attracted little notice, and shares in Warner-Lambert - a company that also owned Lipitor (atorvastatin) - soared to their highest ever on the New York Stock Exchange when the licence for use in combination with insulin was granted (Fig. 1), and were set to rise still further. Uptake of the new agent was unprecedented, such that troglitazone had already captured $12 \%$ of the US market for oral agents for diabetes by July 1997 [14]. This was driven by a marketing campaign targeted directly towards patients, which, despite disclaimers, conveyed the message that this pill could save them from going on to insulin.

Retrospective analysis does not convey the excitement that many people felt about troglitazone. The thiazolidinediones represented a totally new therapeutic concept, not to mention a whole new area of scientific enquiry, and the initial results of treatment looked highly promising. A member of the company medical team later told me that the initial mood was one of elation, mixed with concern that the revolutionary benefits of the therapy should be obscured by side effects seen only in a small minority of patients. There were, however, reasons for concern. Peroxisomes are intracellular organelles concentrated within the liver, and the peroxisome proliferator-activated receptor (PPAR) agonists are named for their characteristic of causing these to proliferate. The FDA panel that approved troglitazone noted that rat liver concentrations of the drug were 30 times greater than those in plasma and commented:

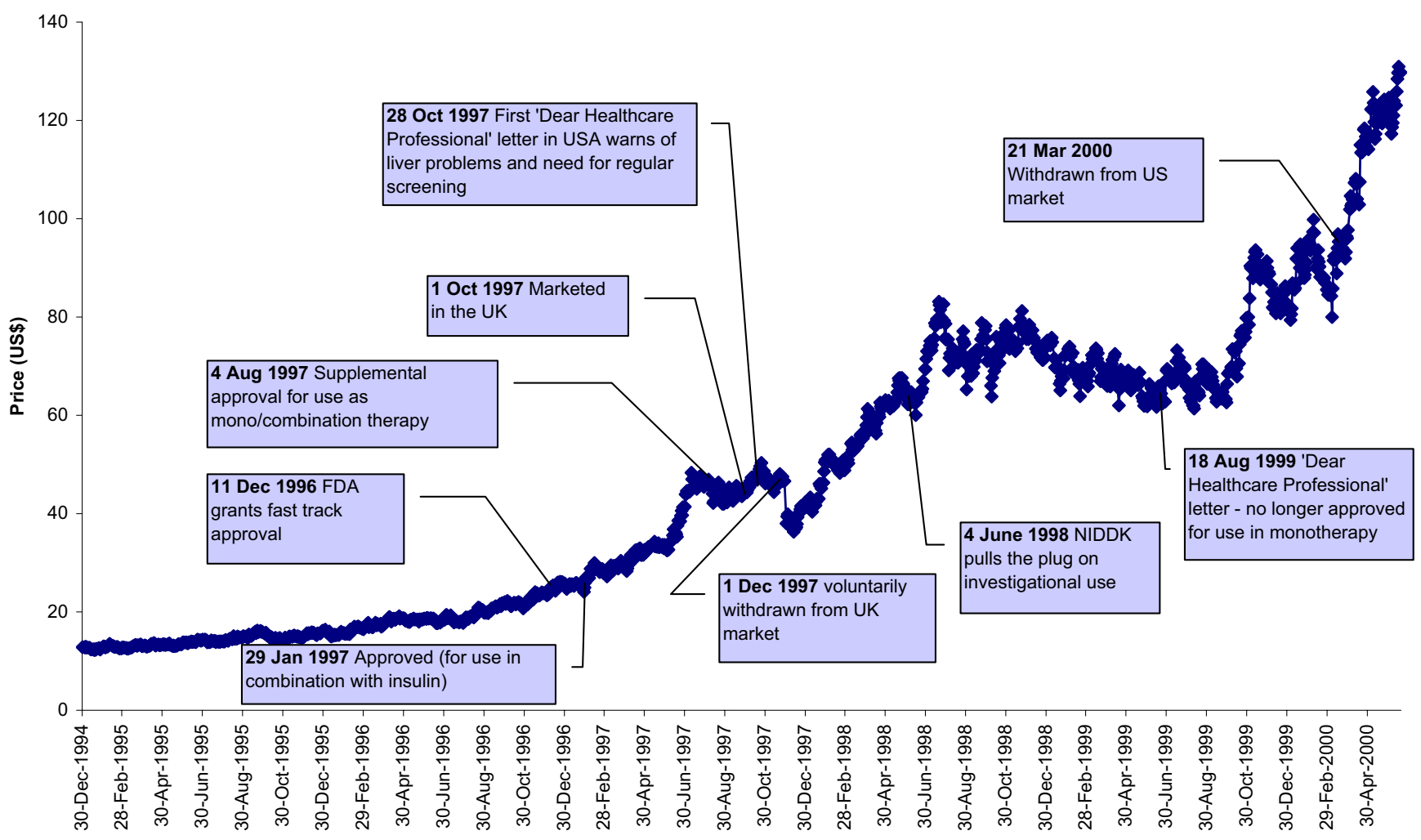

Fig. 1 The closing share price of Warner-Lambert, 1995-2000, in relation to the rise and fall of troglitazone. The company was acquired by Pfizer in 2000. Source: Datastream (Greenville, SC, USA) 
'at least in rats we have reason to be concerned about what might happen ultimately in liver, a target tissue' [12]. A further concern lay in the fact that the thiazolidinediones were not only new drugs; they were a new class of drug. The other agents with which we are most familiar (beta blockers, ACE inhibitors and so forth) inhibit a signalling pathway at a defined site, with relatively predictable consequences. The glitazones are agonists; like steroids, their interaction with nuclear receptors has consequences that are both far-reaching and incompletely understood. The therapeutic switch that would be used to lower plasma glucose had a number of other wires leading away from it whose function was uncertain.

\section{End of a honeymoon}

Troglitazone, meanwhile, was launched in the UK by Glaxo Wellcome in October 1997, and seemed set to become a global best-seller. The honeymoon was brief, for Glaxo Wellcome, alarmed to receive notification from the USA and Japan of 135 cases of serious liver toxicity and six deaths, voluntarily withdrew troglitazone with effect from 1 December 1997 [15]. The accompanying statement said that 'based on present information, the risks of troglitazone therapy outweigh the potential benefits'. Warner-Lambert shares fell by $18.5 \%$, but rallied when it became apparent that the drug would remain on the US market (Fig. 1). The UK was the reporting country for European regulatory approval, and the knock-on effect of this action was such that only Japanese and US citizens were exposed to any further risk relating to the drug.

Sidney M. Wolfe of Public Citizen's Health Research Group wrote to the FDA on 14 March 2000 requesting investigation of the charge that data on liver toxicity, available to the company on 3 February 1997 (before marketing began), were not submitted to the FDA until October 21 st, although federal law required that such data be submitted within 15 days [16]. The company responded that these data were on the product label, and must therefore have been submitted to the FDA [13]. What seems clear is that information released by the company in October 1997, including news of the first deaths in Japan, came as a shock to Glaxo Wellcome and prompted the withdrawal of troglitazone from the UK market. It also triggered alarm at the FDA, and resulted in a series of labelling changes in which physicians were advised to monitor liver function up to ten times in the first year of treatment, despite the unlikelihood that this could be achieved in practice [17]. On the day troglitazone was withdrawn in the UK, Parke-Davis and the FDA issued a 'Dear Healthcare Professional' letter in the USA, which concluded 'you will be reassured to know that the additional reports received since early November do not indicate a greater frequency of liver injury or potential for serious harm than had been previously estimated' [18]. Confirmation of a serious health risk can rarely have been presented in such a positive manner.
The first detailed account of liver toxicity reached the medical public in a letter from company representatives to the New England Journal of Medicine in March 1998. Remarkably enough, this simply restated information already available on the product label 1 year earlier (see above). Of 2,510 patients receiving troglitazone, $48(1.9 \%)$ were now said to have a three-fold or greater elevation in ALT (the package insert said $2.2 \%$ ) as against $0.6 \%$ of controls. Of these, 20 were taken off the drug, and five (one in 500 users) had a 20 -fold increase. The implication was that one in 50 people treated would need to be taken off the drug because of changes in liver enzymes, and that one in 500 would be exposed to the risk of serious liver injury. The letter did not mention the accumulating post-marketing data, or the risk of death, or that the agent was considered too unsafe for use elsewhere in the world [19].

The NIDDK stopped the troglitazone arm of its study in June 1998 [4] but this agent, now deemed too unsafe for investigational use, remained on the US market. On July 27, Sidney M. Wolfe and Larry Sasich, both of Public Citizen's Health Research Group, petitioned Michael Friedman of the FDA to initiate action to ban troglitazone, asking 'how many more Americans will have to die or require liver transplants?' [20]. A number of leading diabetes experts felt moved to write to the FDA in response to this and subsequent challenges, to protest that withdrawal of troglitazone would be unthinkable. Their comments can be accessed in the FDA archives.

\section{Endgame}

The rest of the story can be passed over briefly. Public Citizen continued to petition the FDA to withdraw troglitazone from the market, and many of the allegations it made were later shown to be correct [21]. Leading physicians continued to write in its support, for the most part pointing out that you can't fight a war without taking casualties. As late as 24 March 1999, when the licence for monotherapy was about to be withdrawn in the face of limited efficacy and a mounting death toll, the President and Chair of the Clinical Affairs Committee of the Endocrine Society put their names to a letter to the FDA stating that 'its continued availability is essential' for some patients with type 2 diabetes, and that the drug should continue to be 'widely available' [22].

Troglitazone stayed on the US market for 2 years and 3 months after it had been withdrawn from the UK. No reassuring safety data emerged over this period, and the morbidity and mortality curves could have been extrapolated from information available by late 1997 . The company steadfastly maintained that the drug must be safe because the FDA had approved it, and the FDA was advised by physicians who were, for the most part, convinced that the new agent had unique benefits. The latter view is now hard to justify. The thiazolidinediones were indeed a major scientific breakthrough, but this was not matched by their clinical performance. Metformin, a tried and tested agent 
currently regarded as the drug of choice in type 2 diabetes, was on the US market. Outcome data from the UK Prospective Diabetes Study (UKPDS) showed that it reduced morbidity and saved lives. Ironically, the enthusiastic response with which US physicians greeted troglitazone stemmed from the fact that their only previous treatment options for type 2 diabetes had been sulfonylureas and insulin. By banning metformin, the conservatism of the FDA had created the conditions in which a hastily introduced new agent could flourish. Placebo-controlled trials of troglitazone gave a misleading impression of its potency, and head-to-head comparisons with other agents were largely avoided. Second-rate studies were published in first-rate journals, accepted because of the high level of interest in the new drug, coupled with a lack of reliable information about it [23]. These publications were then considered to endorse its scientific credentials. On the grounds that troglitazone was an essential therapy for diabetes, rosiglitazone and pioglitazone were rushed through the regulatory pathway to take its place, with the result that very little useful information about these agents was available to clinicians at the time of their launch. It was easier to keep troglitazone going until these agents were launched than to revisit the earlier decision to keep the drug on the market.

The campaign against troglitazone was waged from unlikely places. Public Citizen pursued the issue relentlessly, although hampered by lack of support from the medical community. A hard-hitting string of newspaper articles from David Willman of the Los Angeles Times concerning this and other recently marketed drugs won him a Pulitzer Prize for investigative journalism. Decisions previously made in comfortable obscurity were brought into the light of day. Last, but not least, medical officers within the FDA conspired to leak information about the safety profile of troglitazone to leading politicians, and this degree of public exposure (allegedly resulting in disciplinary hearings for the whistleblowers concerned) [3], finally led to withdrawal of troglitazone in March 2000.

\section{Aftermath}

It will never be known exactly how many people died or suffered injury because of troglitazone. The final report of the FDA, drafted by David Graham and issued in December 2000 (Text box) estimated that at least one in 1,000 recipients would experience acute liver failure, but the confidence intervals around the estimate were wide, and others would argue that the true rate was considerably less. By March of that year, 94 cases of acute liver failure had been voluntarily reported to the FDA, resulting in 66 deaths, 11 liver transplants (of whom three died), ten recoveries and unknown outcomes in the remainder. Graham estimated that $10 \%$ at most of such cases had been reported to the FDA [17]. Claims and counter-claims were soon to be aired in litigation, with the effect that informed and dispassionate consideration vanished into a haze of legal argument. Certain conclusions are, however, largely beyond dispute. These are as follows:

1. Liver failure was idiosyncratic and unpredictable, and there was no evidence that regular screening of liver function, even if achieved ten times in the first year of treatment, could offer protection. This was a game of Russian roulette, regardless of the number of empty chambers in the revolver.

2. The evidence upon which the drug was withdrawn in March 2000 could have been extrapolated from data available in October 1997.

3. Troglitazone, despite undoubted benefits in some patients, had no unique advantage over existing medication.

4. Information about the risks of therapy was not freely available to physicians. Too little was released, too late, and false reassurance was repeatedly conveyed.

5. Sales of troglitazone grossed US $\$ 2.1$ billion, equivalent to US $\$ 1.8$ million for every day it was available on the market.

'We estimated the background rate of acute liver failure in the general population to be about 1 case per million persons per year (person-years). Using case reports data supplemented by usage data from a large multi-scale managed care organisation, we estimated the rate of ALF with troglitazone to be about 1 case per 1000 person-years (accounting for underreporting). From three postmarketing clinical studies, the incidence of ALF ranged from about 1,200 to 17,000 per million personyears. Survival analysis suggested that the cumulative risk of $A L F$ with troglitazone increased with continuing use of the drug. The implications of this for a product intended to be used for decades should not be overlooked. Based on a number of different analyses, underreporting of ALF with troglitazone was extensive. This highlights the limitations of voluntary (spontaneous) reporting systems. It also illustrates the danger of using changes in reporting over time as a measure of success of an intervention. Reporting naturally decreases quickly after the start of marketing so that one cannot cite a decline in number of case reports as evidence that a safety problem has been successfully managed. Multiple labeling revisions and Dear Healthcare Professional letters recomending monthly liver enzyme monitoring did not improve the safety profile of troglitazone. Enzyme monitoring was not performed regularly or reliably even after the July 1998 relabeling. Analysis of case reports suggested that even had monitoring been performed, it probably would not have prevented many, or perhaps any, cases of troglitazone-induced ALF. The point of no return that is, of irreversibility and inevitable progression to liver failure appeared to be reached within a month or less of a time when liver enzymes were normal.'

(From the executive summary of the FDA Final Report: Liver failure risk with troglitazone (Rezulin), NDA: 20-720, 19 December 2000 [17] 


\section{The dogs that didn't bark}

The market place is not a moral place; it has only one standard of judgement. By this standard, Warner-Lambert was an outstanding success, with a market value of US $\$ 114$ billion when acquired by Pfizer (as against US\$11 billion in 1995) in a deal announced in February 2000, 6 weeks before troglitazone was withdrawn from the US market. Troglitazone had long since been discounted as a doomed drug by investors, who are remarkably responsive to safety concerns, but its continued presence on the market may have helped to maintain share prices until the merger came through.

This Editorial is not about the evils of Big Pharma, although it may serve to remind readers that such evils exist. As in any other walk of life, there is good practice to balance the bad, and the exemplary behaviour of Glaxo Wellcomesomewhat tarnished by their effort to reintroduce troglitazone in 1999 - should be set against the sorry performance of Warner-Lambert. Codes of practice have been tightened since then, although institutions such as the National Institutes of Health still struggle with conflict of interest, an issue described in a recent commentary as 'an unhappy chapter in the life of a government agency that is also a national treasure' [24]. The system has absorbed some important lessons and moved on. One thing has not changed, however. Despite their carefully cultivated image, pharmaceutical companies are business organisations that must obey the laws of the market or go down. And pharmaceutical companies market to doctors. Their profits derive from the prescriptions we write. What we tolerate, they toleratewhich is why we get the pharmaceutical industry we deserve [25].

This Editorial is about the voices that were not raised when troglitazone was on the market, and the curious collective amnesia that has afflicted the diabetes community ever since. Hundreds of people died or underwent liver transplantation because of troglitazone, and thousands more experienced liver damage as a consequence. This was the most dangerous diabetes therapy since phenformin. And yet the story outlined here, long familiar to readers of the Los Angeles Times, has never to my knowledge been considered at any length in the medical literature, which contains more than 800 papers about troglitazone. Why? On going litigation is estimated to have cost the companies involved some US\$750 million in legal fees and compensation, but the drug still generated a healthy profit and-more importantlyhelped maintain share values until the company was taken over. No inquiry has been held, no one has apologised, no one's career has suffered (with the exception of Richard Eastman), and a lot of people are wealthier in consequence. Clinicians and researchers working with diabetes did well out of troglitazone, and some still talk with nostalgic regret of its wasted potential. The most striking thing about the story is that the medical community remained resolutely silent on the subject of patient safety. No prominent physician, anywhere in the world, ever stood up to say that a pill for diabetes is not worth dying for.
Acknowledgements I thank S. Hawkins and A. Kolb for their assistance in carrying out the research upon which this article is based, and for creating the accompanying website.

Disclaimer The views expressed in this and other Editorials are those of the Editor, and not of the EASD.

Duality of Interest The author has had no financial interest of any sort in the companies mentioned in this article. He has testified as an expert witness in litigation concerning Rezulin; the invitation to do so post-dated a previous article on this topic [23].

Website Further details on the troglitazone story can be obtained from http://www.troglitazone-story.net

\section{References}

1. Anonymous (1999) The Diabetes Prevention Program. Design and methods for a clinical trial in the prevention of type 2 diabetes. Diabetes Care 22:623-634

2. Diabetes Prevention Program Research Group (2002) Reduction in the incidence of type 2 diabetes with lifestyle intervention or metformin. New Engl J Med 346:393-403

3. Willman D (2000) The rise and fall of the killer drug Rezulin. Los Angeles Times, 4 June. Reprint available from http://www. lef.org/magazine/mag2000/sep2000_report_rezulin.html, last accessed in October 2005

4. National Institute of Diabetes and Digestive and Kidney Diseases (1998) NIDDK discontinues troglitazone arm of "Diabetes Prevention Program" clinical trial. NIDDK, Bethesda. Available from http://www.niddk.nih.gov/welcome/releases/ 64 98.htm, last accessed in October 2005

5. Willman D (1998) Drug maker hires NIH researcher. Los Angeles Times, 7 December. Available from http://www.house. gov/waxman/news files/news letters rezulin press NIH sci denies_12_7_98.htm, last accessed in October $200 \overline{5}$

6. Nolan JJ, Lüdvik B, Beerdsen P, Joyce M, Olefsky J (1994) Improvement in glucose tolerance and insulin resistance in obese subjects treated with troglitazone. New Engl J Med 331:1188-1193

7. Olefsky J, Antonucci T, Lockwood D, Norris R. Use of thiazolidinedione derivatives and related antihyperglycemic agents in the treatment of impaired glucose tolerance in order to prevent or delay the onset of noninsulin-dependent diabetes mellitus. US Patent 5,478,852, filed 23 August 1994. Available from http://patft.uspto.gov/netacgi/nph-Par ser?Sect1 $=$ PTO $1 \&$ Sect $2=$ HITOFF $\& d=$ PALL $\& p=1 \& u=/$ netahtm1 srchnum.htm \&r=1\&f=G\&l=50\&s1=5,478,852. WKU\&OS=PN/ $5,478,852 \& \mathrm{RS}=\mathrm{PN} / 5,478,852$, last accessed in October 2005

8. Olefsky J. Use of thiazolidinedione derivatives and related antihyperglycemic agents in the treatment of insulin resistant subjects with normal glucose tolerance in order to prevent or delay the onset of noninsulin-dependent mellitus. US Patent 5,708,012, filed 28 April 1995. Available from http://patft.uspto.gov/netacgi/nphParser?Sect1 $=$ PTO1\&Sect $2=$ HITOFF \&d=PALL \& $p=1 \& u=/$ netaht $\mathrm{ml} / \mathrm{srchnum} . \mathrm{htm} \& \mathrm{r}=1 \& \mathrm{f}=\mathrm{G} \& \mathrm{l}=50 \& \mathrm{~s} 1=5708012$. WKU.\&OS=PN $15708012 \& \mathrm{RS}=\mathrm{PN} / 5708012$, last accessed in October 2005

9. Varmus H (1998) Letter to Henry A. Waxman, House of Representatives, 29 December. Available from http://www.henry waxman.house.gov/news_files/news_letters_rezluin_2_19_99 $\mathrm{NIH}$ response.htm, last accessed in October 2005

10. US Department of Health and Human Services/Food and Drug Administration (1997) FDA approves rezulin for diabetes patients poorly controlled on insulin therapy. FDA Talk Paper, 30 January. Available from http://www.fda.gov/ bbs/topics/ANSWERS/ANS00783.html, last accessed in October 2005 
11. Anonymous (1995) Warner-Lambert Company. Corporate Crime Reporter 46, 4 December. Available from http://www. corporatecrimereporter.com/top100.html\#Annotated, last accessed in October 2005

12. US Department of Health and Human Services/Food and Drug Administration (1996) Endocrinologic and Metabolic Drugs Advisory Committee. Troglitazone for diabetes mellitus. Meeting no. 65. USDHHS/FDA, Bethesda, 11 December. Available from http://www.fda.gov/ohrms/dockets/ac/96/transcpt/ 3255t2a.pdf; http://www.fda.gov/ohrms/dockets/ac/nscpt/ 3255t2c.pdf; http://www.fda.gov/ohrms/dockets/ac/96/transcpt/ 3255t2d.pdf; all last accessed in October 2005

13. King KF (2000) Letter to Jane E. Henney, Food and Drug Administration. Parke-Davis, Morris Plains, 20 March. Available from http://web.archive.org/web/20001015184650/www. warner-lambert.com/Rezulin/henney.html, last accessed in October 2005

14. IMS Health (1998) Business Watch: 1997 at a glance. IMS Health, Fairfield

15. Anonymous (1997) Troglitazone (Romozin) withdrawn. Current Problems in Pharmacovigilance 23:13-16. Available from http://www.mhra.gov.uk/home/groups/pl-p/documents/publica tion/con007478.htm\#Troglitazone, last accessed in October 2005

16. Wolfe SM (2000) Letter to the FDA requesting a criminal investigation of Warner Lambert/Parke Davis for what appears to be illegally delaying the submission of data known to the company before troglitazone was marketed. HRG Publication \#1515. Public Citizen's Health Research Group, Washington, 14 March. Available from http://www.citizen.org/publications/ print release.cfm?ID $=6716$, last accessed in October 2005

17. Graham D, Green L (2000) Memorandum. Final report: Liver failure risk with troglitazone (Rezulin) NDA: 20-720. USDHHS, FDA, Center for Drug Evaluation and Research, Bethesda. 19 December
18. Sigmund WR 2nd (1997) Dear Healthcare Professional. ParkeDavis, Morris Plains, 1 December. Available from http://www. fda.gov/medwatch/SAFETY/1997/rezul3.htm, last accessed in October 2005

19. Watkins PB, Whitcomb RW (1998) Hepatic dysfunction associated with troglitazone. New Engl J Med 338:916-917

20. Wolfe SM, Sasich L (1998) Petition to the Food and Drug Administration to ban troglitazone/Rezulin due to its causing several cases of liver failure. HRG Publication \#1449. Public Citizen's Health Research Group, Washington, 27 July. Available from http://www.citizen.org/publica tions/release. $\mathrm{cfm} ? \mathrm{ID}=6647$, last accessed in October 2005

21. Wolfe SM (1999) Statement before the Food and Drug Administration Endocrine and Metabolic Drugs Advisory Committee meeting advising them to withdraw troglitazone from the U.S. Market. HRG Publication \#1476. Public Citizen's Health Research Group, Washington, 26 March. Available from http://www.citizen.org/publications/release.cfm?ID=6674, last accessed in October 2005

22. Horwitz KB, Mallin SR (1999) Letter to Endocrinologic \& Metabolic Drug Advisory Committee on Rezulin. Re: Rezulin (troglitazone). Endocrine Society, Bethesda, 24 March. Available from http://www.endo-society.org/publicpolicy/legislative/ letters/fdaletter.cfm, last accessed in October 2005

23. Gale EAM (2001) Lessons from the glitazones: a story of drug development. Lancet 357:1870-1875

24. DeRenzo EG (2005) Conflict-of-interest policy at the National Institutes of Health: the pendulum swings wildly. Kennedy Inst Ethics J 15:199-210

25. Gale EAM (2003) Between two cultures: the expert clinician and the pharmaceutical industry. Clin Med 3:538-541 